\title{
The Cost of Equity Capital on Developing Equity Markets: Estimations for Selected Slovene Companies
}

Igor Stubelj*

Abstract:

The article sheds light on the estimation of the cost of equity capital on a developing equity market. The cost of equity is important; it is crucial in capital budgeting decisions and performance evaluation. It determines the minimum yield the investors require on the invested capital and we use it as a discount rate to calculate the present value of the expected free cash flows to equity. The aim of this paper is to tackle the estimation of the cost of equity capital on developing markets with the example of estimation for ten Slovene publicly traded companies. The estimated cost of capital for the selected Slovene companies is between $9,7 \%$ and $13,7 \%$.

Keywords: cost of equity capital, CAPM, return, risk

JEL: G12, G31, G32

DOI: $10.2478 / v 10033-010-0006-3$

\section{Introduction}

The cost of equity capital is important; it determines the minimum yield investors require on invested capital. We use the cost of equity to discount to present value the expected cash flows that belong to equity investors. We use the cost of equity capital to estimate the residual income of a company; i.e. the added value that belongs to the equity investors (Stubelj at al. 2009). The yield at the level of the cost of capital is not an added value for a company; it is a cost. It is the investors' capital investment repayment for the lost opportunities and the risk.

The equity capital does not "work" for free. We must pay a certain price to its owners. It is a scarce good. In aggregate it is limited to the amount that people in the whole world are willing to save (invest). The task of earning the cost of capital is not a question of company financing, as many managers believe. To earn the cost of capital is the market mandate (Stewart 1999).

In the oft-cited publication Stocks, Bonds, Bills, and Inflation, Ibbotson and Sinquefeld wrote: "Estimating the cost of capital is one of the most important and difficult tasks performed by financial analysts. There is no clear consensus on the best way to approach this problem.
Because of the impact that the cost of capital can have on valuation and financial decision making, the analyst should typically use at least two methods to derive the cost of equity" (Ibbotson Associates 1997, in Borgman and Strong, 2006, p. 7).

The cost of equity capital estimation is especially problematic and difficult on developing markets. Most of the models, CAPM included, are based on historical data. In developing financial markets (like the Slovenian) there is a short time series of usable data. Estimation with some models used for developed financial markets is impossible.

The purpose of this paper is to summarize the theory, present relevant research in the field, and present the available methods for cost of equity capital estimation and their suitability for use on developing capital markets. The aim is to tackle the estimation of the cost of

\footnotetext{
* Igor Stubelj

University of Primorska's Faculty of

Management in Koper

E-mail: igor.stubelj@fm-kp.si
} 
equity capital on developing markets with the example of estimations for ten publicly traded Slovene companies.

The paper is organized as follows. After the introduction the theoretical background of equity capital estimation is presented. In addition, we explain the estimation's methodology and the results. Finally, we present conclusions.

\section{Theoretical Background}

A primary division of equity capital is into common and preferred, which means that companies can get equity capital with the issue of either common or preference shares. Companies can raise common equity also by retaining earnings. If a company raises equity by issuing new shares it must also cover the issue costs, which represent an additional cost the company must earn. For this and other reasons few mature firms issue new shares (see Brigham and Ehrhardt 2005, p. 311).

The equity raised by retained earnings also bears a cost; it is not costless. It is the opportunity cost of the investor who can get dividends from his part of the net income and invest the capital somewhere else. The investor expects a relevant risk adjusted return or the return of an investment which bears comparative risk.

The cost of preferred equity is simple to calculate when the market price is known because of fixed obligations (fixed dividends). A difficult task is the estimation of the cost of common equity. Many models and techniques have been developed to estimate the cost of equity capital, such as: the Capital Asset Pricing Model (CAPM) (Black 1972, Lintner 1965, Ross 1976, Sharpe 1964), the Fama and French Three Factor Model (Koller e.a. 2005, Estrada 2005), the Arbitrage Pricing Theory, among others. Mishra and O'Brien (2004) have studied the empirical perspective on the issue of global investors' cost of capital for an emerging market investment.

\subsection{The Estimation of the Cost of Common Equity Capital with the CAPM (Capital Asset Pricing Model)}

The CAPM states that the required return for investors is the sum of the risk-free rate and the market risk premium, multiplied by beta. Beta defines the risk contribution of the added stock to a well diversified portfolio. The CAPM supposes that all investors hold a combination of a risk-free investment and a well diversified (market) portfolio. In such case they reach a maximum return with a minimum risk. The proportion of the diversified portfolio and risk-free investment an individual holds depends on his risk inclination (aversion). The CAPM is based on strong assumptions. Despite the critics, it is the most favored and widely used method for the cost of equity capital estimation (see Bruner et al. 1998, Graham and Harvey 2001, Brigham and Ehrhardt 2005). Interesting results were yielded in a study Gunnlaugsson (2006) made on the validity of the CAPM on the small Icelandic stock market. They indicate that the CAPM has worked well in the small Icelandic stock market and that it, or the beta coefficient, does explain returns better than on larger foreign stock markets. A strong relationship between the beta and stock returns was found in the research. Further, the stock returns with high betas were higher than one would expect, according to the CAPM. The limitations of the research are that it was tested on small number of shares (27) and a short time series of data was used. McNulty et al. (2002) found three central shortcomings of the CAPM: a) the validity of beta, b) the reliance of historical data and c) the indifference of holding period (Zellweger 2007, p. 1).

The primary conclusion of the CAPM (Eq.1) is that the relevant risk of an individual stock is its contribution to the risk of a well diversified portfolio. The CAPM is calculated as follows:

$r_{i}=r_{f}+\beta \cdot\left(r_{m}-r_{f}\right)$,

where $r_{i}$ is required rate of return on investment, $r_{f}$ is risk-free rate of return, $\beta$ is measure of the market risk, $r_{m}$ is market rate of return, $\left(r_{m}-r_{f}\right)$ is market risk premium.

A lot of models used in finance use a risk-free investment which bears a known risk-free rate of return as a base. The first step is the estimation of the risk-free rate of return. When we estimate the risk investment we expect a risk-free rate of return and an extra return for bearing the risk. Consequently, the first problem to deal with is the evaluation of the risk-free rate of return. The question is which asset is risk-free. Every asset has a life period in which it must earn an expected return. With the increasing probability that the return of the asset in its life period will be different from that expected the risk increases. In finance we define the risk as a deviation of the actual from the expected return. In financial circles we call investments risk-free when the actual return is equal to the expected return. The probability of default must be equal to zero and reinvestment must always be possible.

When we estimate a cost of capital and when we determine a risk-free rate we must pay attention to the life period of the asset. The equity capital invested in a 
firm has an unlimited life. So, it is recommended to use an asset with a long life as a risk-free investment. A good approximation of a risk-free investment can be a longterm government bond. We must be careful that the bond we use (usually a 10 to 30 year to maturity bond) is liquid. In this case his yield can be a good approximation of a risk-free rate for current market conditions.

In special cases we can use the government bond of a developed equity capital market. In such a case we must consider different inflation rates in different countries. The inflation indexed bond has solved this problem. We add the expected country inflation to the real bond yield and this represents a risk-free rate of return.

The next step is the estimation of the market risk premium. In their study, Ferson and Locke found that the estimation of the market risk premium is much more important than the estimation of the beta coefficient (Ferson and Locke 1998). Bigger errors in the cost of capital estimations are the outcome of the errors in the estimation of the market premiums. This means that the analysts must improve the methods of market risk premium estimation, which is based on historical data. Bartholdy and Peare found out that we must use the same approximation for the market portfolio when we estimate the market risk premium and the beta. Using different approximations most likely yields a biased estimate (Bartholdy and Peare 2000).

The market risk premium is mathematically expressed as the difference between the market and the risk-free return. We have different options to evaluate the market risk premium: (1) from the expectations of different investors or from an expert's recommendations, (2) from historical data (past returns), (3) from the expected returns, which is the forward looking market risk premium.

Because every investor has his own expectation about the adequate market risk premium, we can calculate a market risk premium as a weighted average of the different investors' expected premiums. This method is rarely used in practice; estimated premiums are very volatile and short-term (Damodaran 2006, p. 38).

In case the investors' risk aversion did not change significantly in the past we can say that the historical risk premium is a good proxy for the expected risk premium. We calculate the historical risk premium from a long-term series of assets' (stocks and bonds) historical returns. The market risk premium is calculated as the difference of the average of stocks and risk-free bonds' annual returns for long-term periods. For some developed markets we have historical data of returns for eighty or more years. The time period used is important. Some experts advocate shorter time periods with the argument that the risk premium scientifically changes in time. Using a shorter period of time we obtain a more realistic estimation. On the other hand, shortening the time series increases the sample standard error. The differences in errors are so big that the use of shorter periods is not reasonable (Damodaran 2006, p. 39). This is proved by the research of Koller et al. (2005). From the data of the last 100 years they did not find statistically significant trends in market risk premium changes. The premium was very volatile; it reached $18 \%$ in the fifties and $0 \%$ in the seventies. In absence of trends and because of the intense volatility of the premium it is recommended to the longest periods possible.

The calculation of historical risk premiums is limited to financial markets with a long history of data. For developing financial markets the time-series of past returns is too short to calculate market risk premiums.

It is possible to estimate the risk premium without using past data with the Gordon Growth Model for the valuation of shares. This is the implied equity premium or forward-looking risk premium. The method is based on a presumption that the entire market is properly valuated. Fama and French (2002) have studied net incomes and dividends' growth rates on the American financial market between the years 1951 and 2000. They estimated a 2,55\% future risk premium.

The question is which is the proper market risk premium for the Slovene market? It is certainly higher than for a mature equity market; the Slovene equity market is a developing market. The liquidity of stocks rose in the last years in Slovenia, but is still low in comparison with developed financial markets, if we compare the turnover of the market capitalization for more liquid stocks. The market capitalization of the three biggest companies represents $50 \%$ of the entire market capitalization of shares which trade on the Ljubljana stock exchange, measured on 5th April 2007 (Stubelj 2009). The Slovene equity capital market is relatively inefficient, similar to other segments of the Slovene financial market (Dolenc 2007), and has been mostly driven (at least at its beginning) by privatization transactions (Dolenc 2006).

\section{The estimation of beta from historical data}

The conclusion of the CAPM is that the only relevant risk of an individual stock is its contribution to the risk of a 
well-diversified portfolio. We measure the risk contribution of an individual stock to a well-diversified portfolio with the beta coefficient. For a market portfolio $\beta=1$. An investment with $\beta=1$ is of average risk, with $\beta<1$ less risky and with $\beta>1$ more risky than an investment of average risk. We define beta with the following equation.

$$
\beta=\frac{\operatorname{Cov}_{i, m}}{\sigma_{m}^{2}},
$$

where $\operatorname{Cov}_{i, m}$ is covariance between returns of the investment and a market portfolio, $\sigma_{\mathrm{m}}{ }^{2}$ is variance of returns of a market portfolio.

We usually calculate beta using linear regression. Beta is a slope in the linear regression equation where the dependent variable is the past returns of an individual investment and the independent variable is the past returns (a proxy) of a market portfolio. Different financial institutions such as Thomson Financial, Bloomberg and Yahoo calculate betas with slightly different methods and their betas for the same shares are different. Analytics usually use 4 to 5 years of monthly returns, while some prefer 52 weeks of weekly returns (Brigham and Ehrhardt 2005, p. 153). Robert Merton (1980) in his research proved that the use of shorter periods of returns improves the results. But the Merton theory is illusive. The use of daily or weekly returns is problematic when the trading of a share in not frequent. In a period of no trading the illiquid share will have a return equal to zero. But this doesn't mean that the price of the share is stable. The more frequent the periods of non-trading, the more the value of beta is biased and pushed downward. It is recommended to use monthly returns (Koller et al. 2005, p. 309). For use of beta in the CAPM model we suppose that the future beta will be equal to the calculated past beta. Other methods for beta evaluation are: fundamental betas, accountant betas, industrial betas and valuation with the combination of these models. For the explanation of these models see Damodaran (2006). Because of the short history of data and the small number of comparable companies most often these methods are either impossible or difficult to use in developing equity markets.

An interesting method is the beta estimation method, developed and issued by Borgman and Strong (2006). They have used a combination of the CAPM and Gordon dividend growth model. Evaluated betas using this method are useful for fast changing industries where past performance is not a good proxy for the future. The model developed by Borgman and Strong is based on the presumption that due to market competition we can affirm that companies in the long run will have net incomes on the level of capital costs. This means that the expected return in the long run will be equal to the return on equity capital ROE. Here the problem is the evaluation of the growth rate of dividends. The authors have used the expected growth rate from the Value Line database. This is the growth rate forecasted from financial analytics. For most developed markets forecasted growth rates didn't exist and this is an obstacle to the use of this model. For the estimation of beta some financial institutions, Bloomberg for example, use smoothing. These are corrected betas and are pushed toward 1. The aim of smoothing is to reduce the estimation error.

\subsection{The Evaluation of the Cost of Equity Capital with the Expected Discounted Equity Cash Flows}

We start with the dividend-Gordon Growth Model to calculate the equity capital required rate of return. This holds on presumption that the market is in balance. In this case the expected return is equal to the investors' required return of equity capital (Brigham and Ehrhardt 2005, p. 317).

For this calculation we need three input variables: the current stock price, the current dividend, and the expected growth rate, which is difficult to evaluate. When the growth of the company was stable in the past it is possible to suppose the same trend for the future. In practice we seldom find stable past growth and we must be very careful with such estimation. We can estimate the future growth rate with the retained earnings model. The future growth of dividends is the product of ROE and the share of retained earnings. For the future growth of dividends we can consider the financial institutions' estimations. In some databases we can find analyses for bigger companies around the world and American corporations. Different studies show that the specialists' forecasts are a good evaluation of future growth (Harris 1986, p. 66).

When we expect that the future growth rate will change in the future we can evaluate the expected cost of equity capital with a two or multi-stage model. This especially holds for fast growth companies for which we expect that the growth will diminish and stabilize in the next few years. 


\subsection{Other Models for the Estimation of the Cost of Equity Capital}

An interesting model is the three factor model that was developed in 1992 by Fama and French (Koller et al. 2005, Estrada 2005). The model is based on the statement that the return on equity capital is inversely correlated with the size of the company (market capitalization) and positively correlated with the ratio of book to market value of the company equity capital.

The well known APT model (Arbitrage Pricing Theory) model can include more than one factor to explain the relationship between risk and return. Rather than specifying that the required stock returns depend on one factor, namely the rate of return on the market in the CAPM, one could define required and realized rate of returns on individual stock as a function of various fundamental economic factors (Brigham and Ehrhardt 2005, p. 197). This model is theoretically very interesting but not very applicable in practice.

Nagel, Peterson and Prati (2007) have conducted empirical tests on different cost of equity estimation methods based on historical returns. In the direct comparisons of these methods they have found that the best ex-ante estimation method available to financial managers is essentially the CAPM with beta restricted to one; that is, a naïve model where the cost of equity capital equals the risk-premium added to the risk-free rate.

\section{Estimation of the Cost of Equity Capital for the Selected Slovene Companies}

We have selected ten publicly traded companies. The companies are traded on the Ljubljana Stock Exchange and their stocks are listed in the prime and standard equity market. All ten are part of the stock exchange index SBI20 and form the index with five other stocks. We selected these stocks on the basis of data availability and their liquidity. These are the most liquid stocks with the data available for the last four years, the time period we used to calculate the beta coefficients. The selection and the estimation of the equity capital just for the liquid stocks is a limitation of our research.

Considering the conclusions of relevant research and established facts we decided on CAMP, being the most widely used method for the cost of equity capital estimation, and the most relevant for the properties of the Slovene equity capital market, which is small with a short history of available data, all described in the theoretical part. The use of a more complex model with more input variables will increase the estimation error. For the estimation with CAPM we need three input variables; (1) risk-free rate of return, (2) market risk premium and, (3) beta coefficient.

\section{Risk-Free Rate of Return}

We have calculated the risk free rate as the sum of the Yield to Maturity of a 30-year inflation indexed US Treasury Bond and the upper limit of the ECB target inflation. We have used the ECB target inflation rate as the best estimate of the future inflation in Slovenia (EMU area). We expect that the future inflation in Slovenia will be in line with this target.

$r_{f}=Y T M_{a}+i=2,6 \%+2 \%=4,6 \%$

where $r_{f}$ is risk free rate, $Y T M_{a}$ is Yield to Maturity of a 30-year inflation indexed US Treasury bond (Federal Reserve Bank of St. Luis 2009), $i$ is the ECB target inflation rate $(<2 \%)($ ECB 2009).

\section{Market Risk Premium}

Different methods for the market risk premium are explained in the theoretical part but we are limited here. No expert reports for the expected market risk premiums exist. For most emerging markets a long history of data is not available. In Slovenia we have data for just about 15 years and this data is under question because of big changes in the market in the period of transition and the low liquidity of the market. We decided to calculate the risk premium using the method we have found on the Damodaran web site (2009). The method calculates the market risk premium based on a market risk premium of a mature US market, adding a country risk premium. Slovenia has a rating $\mathrm{Aa} 2$, that is $1 \%$ point of additional premium for default risk. The additional premium for default risk is calculated as a difference between the yields to maturity of a Slovene Treasury bond and US treasury bond. According to Damodaran, the adjusted market risk premium for the US market is $5 \%$ and the global average of equity to bond market volatility is 1,5 . 
The calculation of the additional country risk premium for Slovenia:

$$
R P_{s}=P T_{t n} \cdot\left(\frac{\sigma_{g d}}{\sigma_{g o}}\right)=1 \% \cdot 1,5=1,5 \%,
$$

where $R P_{s}$ is the additional risk premium for the Slovene market on the risk premium for a mature US market, $P T_{t n}$ is the additional default risk premium, $\sigma_{g d}$ is the standard deviation of stock returns for the global market, and $\sigma_{g o}$ is the standard deviation of bond returns for the global market.

To get the risk premium for the Slovene market we have added the above calculated additional country risk premium for the Slovene market to the risk premium for the US market.

$$
R P=\left(r_{m}-r_{f}\right)=R P_{z t}+R P_{s}=5 \%+1,5 \%=6,5 \% \text {, }
$$

where $R P$ is ( $\mathrm{rm}-\mathrm{rf}$ ) is the market risk premium for the Slovene market, $R P_{z t}$ is the market risk premium for the US market, $R P_{s}$ is the additional risk premium for the Slovene market on the risk premium for a mature US market.

\section{Measure of the Market Risk-beta}

We have estimated the beta coefficient from the past data. With regard to the data available on the Slovene capital market, using a more complex model will increase the estimation error. We have used a linear regression analysis. The independent variable was the proxy of the market portfolio return. The dependent variable was the market stock return. We have used the return of the market Index SBI20 which illustrates the Slovene equity market. We downloaded daily data on index and share prices from the Ljubljana Stock Exchange (2009) web site for the last four years (from January 2005 to January 2009).

Analytics advocate different time intervals of returns for the calculation of beta. For the purpose of reducing subjectivity we have calculated the average $\beta$ out of the three estimated betas with a different choice of data. We have used the data for the past four years in cases of intervals of 20 trade day returns, two years of data in cases of ten trade day returns and one year of data in cases of five trade day returns. Analytics usually use monthly or weekly returns. With the change of intervals on trading days we simplified the calculation. With this change we eliminate the disturbances of non-trading days. We have calculated the share and index returns with the equations below. The date of the end of the previous interval is also the date of the start of the next interval.

Market index interval return

$r_{i}=\frac{V_{0+t}}{V_{0}}-1$

where $r_{i}$ is the interval market index return, $V_{0}$ is the value of the index on the interval start date, $V_{0+t}$ is the value of the index on the interval end date, $t$ is the length of the interval in days; 5,10 or 20.

Interval market return of stock

$r_{i}=\frac{P_{0+t}}{P_{0}}-1$

where $r_{i}$ is the interval market return of stock, $P_{0}$ is the market value of stock on the interval start date, $P_{0+t}$ is the market value of stock on the interval end date, and $t$ is the length of interval in days; 5,10 or 20 .

In the example below we can see the regression analysis for the beta estimation of the pharmaceutical company Krka, d.d. stock with the 20 trading days intervals of returns.

\begin{tabular}{|c|c|c|c|c|c|}
\hline \multirow{2}{*}{ Model } & \multicolumn{2}{|c|}{$\begin{array}{c}\text { Unstandardized } \\
\text { Coefficients }\end{array}$} & $\begin{array}{c}\text { Standardized } \\
\text { Coefficients }\end{array}$ & \multirow{2}{*}{$\mathrm{t}$} & \multirow{2}{*}{ Sig. } \\
\cline { 2 - 4 } & $\mathrm{B}$ & $\begin{array}{c}\text { Std. } \\
\text { Error }\end{array}$ & Beta & & \\
\hline $\begin{array}{c}1 \text { (Constant) } \\
\text { SBI20 }\end{array}$ &, 013 &, 007 & & 2,045 &, 046 \\
, 829 &, 097 &, 779 & 8,506 &, 000 \\
\hline
\end{tabular}

Dependent variable: Krka, d.d.

Table 1: Results of the linear regression for the estimation of beta of the stock of the pharmaceutical company Krka, d.d. with 20 trading days intervals of returns. 


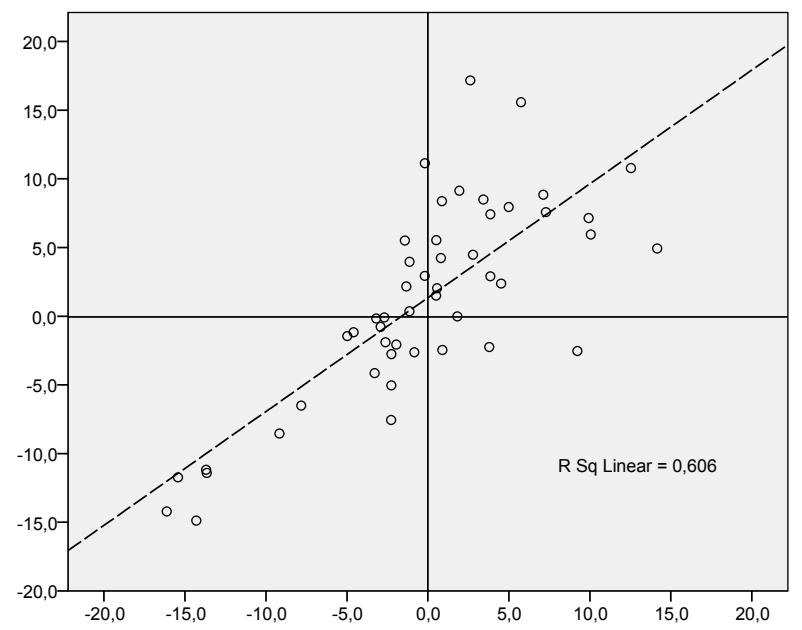

Figure 1: Scatter plot; dependent variable marker returns of Krka, d.d., independent variable market returns of SBI20

From the above linear regression we can write the following equation.

$$
\hat{R}_{K R K A}=\alpha+\beta \cdot R_{S B I 20}=0,013+0,829 \cdot R_{S B I 20}
$$

where $\hat{R}_{K R K A}$ is the expected market return of the stock Krka, d.d., $R_{S B 120}$ is the return of the market index $\mathrm{SBI} 20, \alpha$ is the intercept, $\beta$ is the slope - beta coefficient.

We have done the test of variance ( $F$ test) and found that the differences between betas, estimated with the use of different time intervals of returns, are not statistically significant (see Table 2). However we have used the average betas for our estimation.

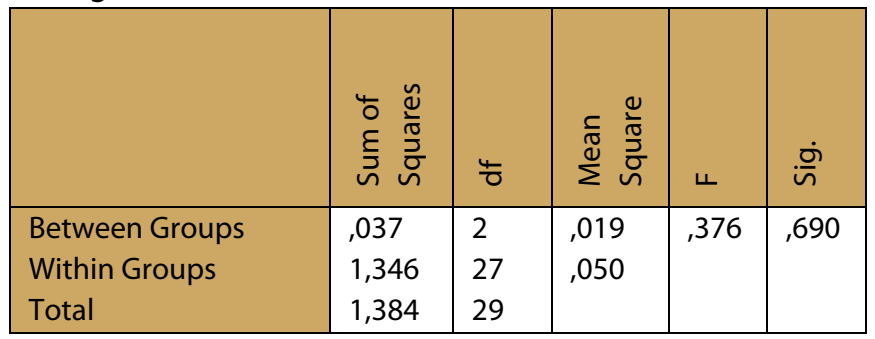

Table 2: The analysis of variance for the betas estimated with the use of different time intervals

In developed markets like the US market we can also calculate betas with the above method or we simply just look for the betas on the web pages of Bloomberg, NYSE, Damodaran online or other financial web sites.

We have estimated all the input variables for the CAPM.

$r_{K R K A}=r_{f}+\beta_{K R K A} \cdot\left(r_{m}-r_{f}\right)=4,6 \%+0,86 \cdot 6,5 \%=10$ where $r_{K R K A}$ is the required rate of return on Krka, d.d., $r_{f}$ is the risk-free rate of return, $\beta_{K R K A}$ is the measure of the market risk for Krka, d.d., $r_{m}$ is the market rate of return, $\left(r_{m}\right.$ $\left.-r_{f}\right)$ is $\mathrm{RP}_{\mathrm{ZT}}-\mathrm{RP}_{\mathrm{S}}$ the market risk premium.

\begin{tabular}{lccccc} 
Company & $\beta_{20}$ & $\beta_{10}$ & $\beta_{5}$ & Average $\beta_{\text {i }}$ r (\%) \\
\hline Aerodrom Ljubljana, & 1,20 & 1,34 & 1,31 & 1,28 & 12,9 \\
Gorenje, d.d. & 1,12 & 1,25 & 1,25 & 1,20 & 12,4 \\
Intereuropa, d.d. & 1,14 & 1,14 & 1,14 & 1,14 & 12,0 \\
Istrabenz, d.d. & 1,42 & 1,39 & 1,39 & 1,40 & 13,7 \\
Krka, d.d. & 0,83 & 0,88 & 0,88 & 0,86 & 10,2 \\
Luka Koper, d.d. & 1,23 & 1,32 & 1,32 & 1,29 & 13,0 \\
Mercator, d.d. & 0,80 & 0,77 & 0,77 & 0,78 & 9,7 \\
Petrol, d.d. & 1,16 & 1,26 & 1,26 & 1,23 & 12,6 \\
Pivovarna Laško, d.d. & 1,00 & 0,73 & 0,73 & 0,82 & 9,9 \\
Sava, d.d. & 0,91 & 0,99 & 0,99 & 0,96 & 10,8 \\
\hline Weighted average & 1,02 & 1,04 & 1,03 & 1,03 & 11,3 \\
\hline
\end{tabular}

Note: We used market capitalization of selected companies as of January 31th 2009 as weights for calculation of weighted average.

Table 3: Estimated cost of equity capital for selected Slovene companies

\section{Conclusion}

The aim of this paper was to tackle the estimation of the cost of equity capital on developing markets with the example of estimation for ten Slovene publicly traded companies.

The cost of equity capital is the risk adjusted return the investors require on invested capital. In the company's valuation the cost of equity capital is used as a discount factor for estimation of the present value of expected cash flows that belong to equity investors.

Especially problematic is the estimation of the cost of capital on developing financial markets. CAPM and most of models are based on historical data. Developing capital markets like the Slovenian market have a short history of available data which makes estimation with some models in use on mature financial markets impossible. Beside this, the data is very volatile. The intense volatility of data is the consequence of changes in the business environment. In the last fifteen years of adaptation to a capital market and in the last years to the global financial market in Slovenia many changes occurred. Models for the cost of equity capital estimation are suitable for companies in developed capital markets. For the estimation we chose the CAPM, which has been criticized begause of the hard presumptions on which the model is based. Surveys indicate that despite the critics it is the 
most widely used and reliable method for the cost of equity capital estimation (see Bruner et al. 1998, Graham and Harvey 2001, Brigham and Ehrhardt 2005). In the CAPM we used the average $\beta$ that was calculated on the basis of three estimated betas with a different choice of stock return intervals. In calculating betas we have used 20, 10 and 5 trade day returns. This helped to reduce the subjectivity in choosing the intervals and eliminated the disturbances of non-trading days.

We have estimated that the cost of equity capital for the selected Slovene companies is between $9,7 \%$ and $13,7 \%$. The limitation is that we have estimated the cost of equity capital for the selected and most liquid stocks on the market. $[$.

\section{References}

Bartholdy, J. and P. Peare. 2000. "Estimating Cost of Equity". Available at SSRN: http://ssrn.com/abstractis 252270 or DOI: 10.2139/ssrn.252270 (accessed February 2, 2009)

Black, F. 1972. "Capital Market Equilibrium with restricted Borrowing". Journal of Business 45: 444-455.

Borgman, R. H. and R. A. Strong. 2006. "Growth Rate and Implied Beta: Interactions of Cost of Capital Models". The Journal of Business and Economic Studies 12 (1): 1-11.

Brigham, E. F. in M. C. Ehrhardt. 2005. Financial Management: Theory and Practice. Ohio: Thomson, South-Western.

Bruner, R.F., K. Eades, R. Harris and R. Higgins. 1998. "Best Practices in Estimating the Cost of Capital: Survey and Synthesis". Financial Practice and Education 8 (1): 13-28.

Damodaran, A. 2009. Damodaran Online. http://pages.stern.nyu.edu/ adamodar/ (accessed February 4, 2009)

Damodaran, A. 2006. Damodaran on Valuation. New York: John Wiley \& Sons, Inc.

Dolenc, P. 2006. "State-owned financial assets and privatization: theory and reality in Slovenia". Naše gospodarstvo 52(3/4): 65-82.

Dolenc. P. 2007. "Public debt management in Slovenia: an empirical analysis". In Bojnec, Š. (ed.). Managing global transitions: globalisation, localisation, regionalisation, (International Management Conference). Koper: Faculty of Management: 1025-1034.

Estrada, J. 2005. Finance in a Nutshell: a no-Nonsense Companion to the Tools and Techniques of Finance. Harlow, England: Prentice Hall.

European Central Bank. 2009. Monetary policy.

http://www.ecb.int/mopo/html/index.en.html (accessed February 4, 2009)

Lintner, J. 1965. "The Valuation of Risk Assets and the Selection of Risky investments in Stock Portfolios and Capital Budgets". Review of Economics and Statistics 47: 13-37.

Ljubljana Stock Exchange. 2009. Data archives.

http://www.ljse.si/cgi-bin/jve.cgi?docis2069\&sidisvCZohilBeCC9ImQJ (accessed February 4, 2009)

Fama, E. and K. R. French. 2002. "The Equity Risk Premium”. Journal of Finance 57 (2): 637-659.

Federal Reserve Bank of St. Luis. 2009. Economic Data - FRED ${ }^{\oplus}$. http://research.stlouisfed.org/fred2/series/TP30A29/downloaddata?cidis 82 (accessed February 4, 2009)
Ferson, W. E. and D. H. Locke. 1998. "Estimating the Cost of Capital Trough Time: An Analysis of the Sources of Error". Management Science 44 (4): 485-500.

Graham, J. R. and C. R. Harvey. 2001. "The Theory and Practice of Corporate Finance: Evidence from the Field". Journal of Financial Economics 60: 187-243.

Gunnlaugsson, S. B. 2006. "A Test of the CAPM on a Small Stock Market". The Business Review, Cambridge 6 (1): 292-296.

Harris, R. S. 1986. "Using Analysts' Growth Forecasts to Estimate Shareholder Required Rates of Return". Financial Management 15 (1): 5867.

Koller, T., M. Goedhart and D. Wessels. 2005. Valuation: Measuring and Managing the Value of Companies. New Jersey: John Willey \& Sons.

McNulty, J. J., Yeh, T.D., Shulze, W.S., and Lubatkin, M.S. 2002. "What's your real cost of capital?" Harvard Business Review 80 (10): 114121

Merton, R. 1980. "On Estimating the Expected Return on the Market". Journal of Financial Economics 8: 323-361.

Mishra, D. R. and O'Brien, T. J. 2004. "Risk and Ex Ante Cost of Equity Estimates of Emerging Market Firms". Available at SSRN: http://ssrn.com/abstractis570721 (accessed February 4, 2009)

Nagel, G. L., D. R. Peterson and R. S. Prati. 2007. "The Effect of Risk Factors on Cost of Equity Estimation". Quarterly Journal of Business and Economics 46 (1): 61-87.

Ross, S. A. 1976. "The Determination of Financial Structure: The Incentive-Signaling Approach". Bell Journal of Economics 8: 23-40.

Sharpe, W. F. 1964. "Capital Asset Prices: A Theory of Market Equilibrium under Conditions of Risk". Journal of Finance 19: 425-442.

Stewart, B. G. 1999. The Quest for Value: a Guide for Senior Managers. New York: HarperBusiness.

Stubelj, I. 2010. “The Valuation of Slovene Publicly Traded companies with a Valuation Model Based on Expected Earnings and Growth Opportunities". Managing Global Transitions 8 (1).

Stubelj, I., M. Jerman and P. Dolenc. 2009. The Analysis of Residual Income - the Empirical Evidence from Slovenia. Studia Universitatis BabeşBolyai, Negotia 54 (1): 3-19.

Zellweger, T. 2007. "Time Horizon, Costs of Equity Capital, and Generic Investment Strategies of Firm". Family Business Review 20 (1): 1 15. 